\title{
ELECTROMECHANICAL TRANSIENT PROCESSES DURING SUPPLY VOLTAGE CHANGING IN THE SYSTEM OF POLYMER INSULATION COVERING OF THE CURRENT-CARRYING CORE OF ULTRA HIGH VOLTAGE CABLES
}

\begin{abstract}
Aim. The article is devoted to the analysis of the electromechanical transient processes in a system of three frequency-controlled electric drives based on asynchronous motors that control current-carrying core motion, as well as to the study of the effect of such processes on the modes applying three-layer polymer insulation to the current-carrying core. Technique. The study was conducted based on the concepts of electromechanics, electromagnetic field theory, mathematical physics, mathematical modeling. Results. A mathematical model has been developed to analyze transients in an electromechanical system consisting of three frequency-controlled electric drives providing current-carrying core motion of ultra-high voltage cables in an inclined extrusion line. The coordination of the electromechanical parameters of the system drives has been carried out and the permissible changes in the supply voltage at the limiting mass while moving current-carrying core of ultra-high voltage cables with applied polymer insulation have been estimated. Scientific novelty. For the first time it is determined that with the limiting mass of the currentcarrying core, the electromechanical system allows to stabilize the current-carrying core speed with the required accuracy at short-term decreases in the supply voltage by no more than $27 \%$ of its amplitude value. It is also shown that this system is resistant to short-term increases in voltage by $32 \%$ for $0.2 \mathrm{~s}$. Practical significance. Using the developed model, it is possible to calculate the change in the configuration and speed of the slack current-carrying core when applying polymer insulation, depending on the specific mass of the current-carrying core per unit length, its tension at the bottom, the torque of the traction motor and the supply voltage to achieve stable operation of the system and accurate working of the set parameters. References 12 , figures 7. Key words: electromechanical transient processes, ultra-high voltage cable, mathematical modeling, frequency-controlled electric drives, polymer insulation covering.
\end{abstract}

Цель. Целью статьи является проведение анализа электромеханических переходных процессов в системе из трех частотно регулируемых электроприводов на базе асинхронных двигателей, которые управляют движением токопроводящей жилы, а также исследование влияния таких процессов на режимы нанесения на жилу трехслойной полимерной изоляции. Методика. Для проведения исследований использовались положения электромеханики, теории электромагнитного поля, математической физики, математического моделирования. Результаты. Разработана математическая модель, позволяющая анализировать переходные процессы в электромеханической системе, состоящей из трех частотно регулируемых электроприводов, обеспечивающихх движение токопроводящей жсллы сверхвысоковольтного кабеля в наклонной экструзионной линии. Проведено согласование электромеханических параметров приводов системы и выполнена оценка допустимых изменений напряжения питающей сети при предельной массе движущейся жилы сверхвысоковольтного кабеля с нанесённой на нее полимерной изоляцией. Научная новизна. Впервые определено, что при предельной массе токопроводящей жилы электромеханическая система позволяет стабилизировать скорость перемещения жилы с необходимой точностью при кратковременных уменьщениях питающего напряжения не более чем на 27 \% от его амплитудного значения. Также показано, что данная система является устойчивой к кратковременному увеличению напряэения на 32 \% в течение 0,2 с. Практическое значение. Использование разработанной модели позволяет рассчитывать изменение конфигурации и скорости движения провисающей токопроводящей жслы при нанесении на нее полимерной изоляции, в зависимости от удельной массы жсилы на единицу длины, ее натяжения в нижней точке, момента тягового электродвигателя и величины питающего напряжения для достижения стабильной работы системы и точной отработки заданных параметров. Библ. 12 , рис. 7.

Ключевые слова: электромеханические переходные процессы, сверхвысоковольтный кабель, математическое моделирование, частотно регулируемые электроприводы, нанесение полимерной изоляции.

Introduction. The modern phase of technological development for applying polymer insulation to currentcarrying cores of power-driven cables is characterized by the use of adjustable AC electric drives. These drives are made on the basis of asynchronous motors with frequency control, which have high dynamic and energy performance. At the same time, when two or more adjustable drives are used in one system, the solution to the problem of their electrical and mechanical parameters coordination becomes much more complicated. When choosing the optimal structure of the control unit of the whole system, it becomes necessary to model complex electrodynamic processes, which now is most appropriate to implement using the Matlab/Simulink/Sim-PowerSystems package.

This approach helps to investigate the laws of frequency regulation and determine the most appropriate system regimes for its stability, speed and other indicators [10]. When operating these drives systems, there is also the task of studying their operation stability when changing the supply network parameters, which is especially important in case of maximum mechanical loads of the drives and their power supply from the power supply system with a limited installed capacity of the servicing substation. The use of computer modeling to solve this type of problems makes it possible to significantly reduce the material costs and timing of such systems design.

This research provides an estimation of the operation stability of electromechanical system with vector control of frequency-controlled electric drives considering shortterm changes in the supply network voltage. It is known [10] that the vector control advantages are the high accuracy of diagram optimization at a set speed, the preserva-

(C) V.M. Zolotaryov, M.A. Shcherba, R.V. Belyanin, R.P. Mygushchenko, I.M. Korzhov 
tion of the necessary torque magnitude at low rotational speeds, the smooth operation of the motor and the rapid reaction to load jumps due to the high dynamics of regulation. At the same time, the quantitative analysis of the stability and accuracy of the specified parameters optimization - motion speed and the torque shaft of the drive, are currently insufficiently studied.

The aim of the paper is to analyze the electromechanical transients in a system consisting of three frequency-controlled electric drives based on asynchronous motors that control the current-carrying core motion, as well as the effect of such processes on the modes of applying three-layer polymer insulation to the currentcarrying core.

The paper studies such freelance regimes as the appearance of short-term voltage failures in the supplying three-phase network and short-term increases in this voltage. The study is carried out to coordinate the electromechanical parameters of the system two drives and to evaluate the permissible level of the voltage failure in the supply network at the limiting mass of the moving cable.

The material is based on the computer modeling results of electrical system that includes two induction motors with vector control, using the scientific statements presented in $[7,11]$. Synthesis of the virtual model uses the tools of the Matlab / Simulink computer modeling software package [8], which contains special blocks and demonstration samples dealing directly with the elements and systems of the automated electric drive. The principles of constructing and exploring individual blocks of virtual models are presented in $[6,7]$, and the control systems of electric drives in the monograph [5].

Description of the inclined line. The inclined extrusion line (Fig. 1,a) is in the form of a metal vulcanization pipe, inside of which extrusion and vulcanization (cross-linking) of a polyethylene insulation layer as well as two polymeric semiconductive layers are applied on the current-carrying core of high-voltage and ultrahigh voltage cables. In such a line, the insulation of aluminum and copper current-carrying cores of power cables is made with a cross section of $35-2000 \mathrm{~mm}^{2}$ for a voltage of 10-330 kV. The current-carrying core consists of many twisted and compacted current-carrying cores, which can be divided into 5-7 separately sealed and isolated sectors. A polymeric semiconductive layer $0.4-3 \mathrm{~mm}$ thick is applied to the current-carrying core, on which an insulating layer of high-quality polyethylene with a thickness of up to $28 \mathrm{~mm}$ and another layer of semiconductive polyethylene with a thickness of 0.4-3.5 mm are applied. All three layers are simultaneously applied by extrusion using a triple extrusion head and vulcanized in a vulcanization pipe of continuous vulcanization at $450{ }^{\circ} \mathrm{C}$ in a medium compressed to $16 \mathrm{~atm}$. nitrogen in the gaseous state. This is necessary to ensure the insulation quality, namely to exclude the presence of conductive microcircuits larger than $50 \mu \mathrm{m}$ and groups of closely located microinclusions [4, 12].

The cable current-carrying core with polyethylene insulation and semi-conductive shielding layers applied must move at a speed of $0.3-50 \mathrm{~m} / \mathrm{min}$ inside the vulcanization pipe $172 \mathrm{~m}$ long. The motion is carried out as a result of the effort up to $4.5 \cdot 10^{4} \mathrm{~N}$ electric drive No. 1 (Fig. 1,b).
The principle of line operation, its scheme is shown in Fig. 1 as follows. The current-carrying core wounded on the feeding device cylinder, is passed through the electric drive No. 1 through a triple extrusion head, into which polyethylene insulation melts and a semiconductive polymer are simultaneously fed. The head has three extruders of different capacities: the first (with the highest capacity) for applying a polyethylene insulation layer, and the second for forming semiconductive polymer layers.

In order for the liquid layer of molten polyethylene to be less displaced relative to the current-carrying core axis, a twisting mechanism is additionally applied. It twists the current-carrying core in the direction of its wires approximately at a pitch equal to one currentcarrying core turn around its axis for 30 linear meters of its length. This makes it possible to obtain a cylindrical item with a crust of solidified polyethylene on its surface and avoid the displacement of the polymeric semiconducting and insulating layers relative to the current-carrying core axis, i.e. avoid the polymer layers eccentricity.

The possibility of such technology implementation is provided by a special configuration of the inclined vulcanization pipe. The initial part of the pipe, where the current-carrying core polymer layers are still sufficiently liquid, is practically vertical. Then the pipe bends and in its final part, where the current-carrying core polymer layers are sufficiently hardened, becomes almost horizontal. The bending and cross-section of the pipe are selected from the conditions of inadmissibility of touching its internal surface by polymeric layers of the current-carrying core with all changes in its cross-section, mass, polymeric layers thickness and linear displacement speed.

A current-carrying core with polymeric layers must move in the central part of the vulcanization pipe and can be considered as a heavy material thread. The angle $\alpha$ between the abscissa axis and the line connecting the beginning and the point with coordinates $(x, y)$, as is known from mechanics, can be determined from the expression:

$$
\operatorname{tg} \alpha=\frac{g x}{H},
$$

where $g$ is the weight of heavy material thread per unit length and $H$ is the tension at the lowest point.

Since the manufacture of insulated cable standards of different cross-sections and at different voltages the value of $g$ varies, the profile of the sag thread also varies:

$$
y=\frac{1}{c} x^{2}
$$

where $c=H / g$ is sag constant.

From the equations given, it is clear that the sag constant $c$ should be unchanged to keep the thread profile. Such profile invariance can be made by adjusting the tension force $H$ and correspondingly adjusting the motor shaft of the drive No. 2 (Fig. 1,b), driving the track-type traction device at a constant technological speed $V$ of the current-carrying core motion in the vulcanization pipe. The invariance of the current-carrying core speed is ensured by adjusting the torque of the traction motor. These relationships are the basis for the motion control system of the current-carrying core inside the vulcanization pipe, which bend is determined from the sagging equations of the current-carrying core as a material heavy thread. 


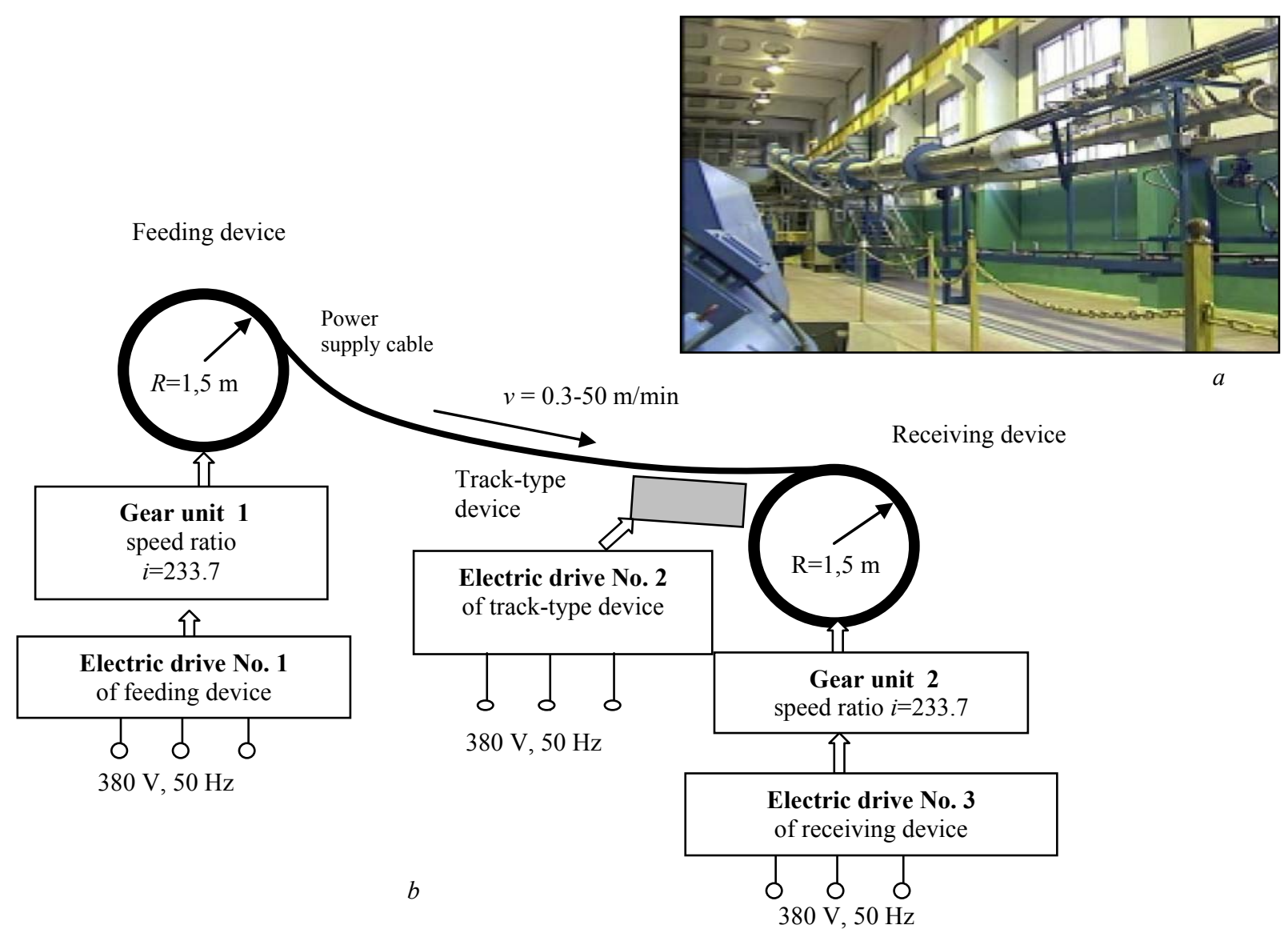

Fig. 1. Inclined extrusion line of applying and vulcanizing a polyethylene insulation layer and two semiconductive layers on current-carrying core of high and ultrahigh voltage cables, $a$ - photo of PJSC «Yuzhcable Works» and $b$ - its block diagram

Problem statement and the development of mathematical model of electromechanical system. The electromechanical system is studied. It is schematically shown in Fig. 1,b and contains three electric drives, based on asynchronous motors with vector control.

Drives No. 1 and No. 3 set in motion the cylinder of the deeding and receiving devices and ensure the cable motion at a constant speed $V$ set by the technological conditions. Drive No. 2 sets in motion the track-type traction

device and provides the required cable tension $H$ when it moves inside the vulcanization pipe. All drives are built based on direct control of the torque and flow of an asynchronous motor (DTC method), described in [1,3,9].

In this paper, as in [7], a mathematical model was developed using the Matlab / Simulink software package [8] to study the electromagnetic processes in electromechanical system shown in Fig. 1. This system model with two electric drives with vector control is shown in Fig. 2.

Electric drive No. 2 of track-type device

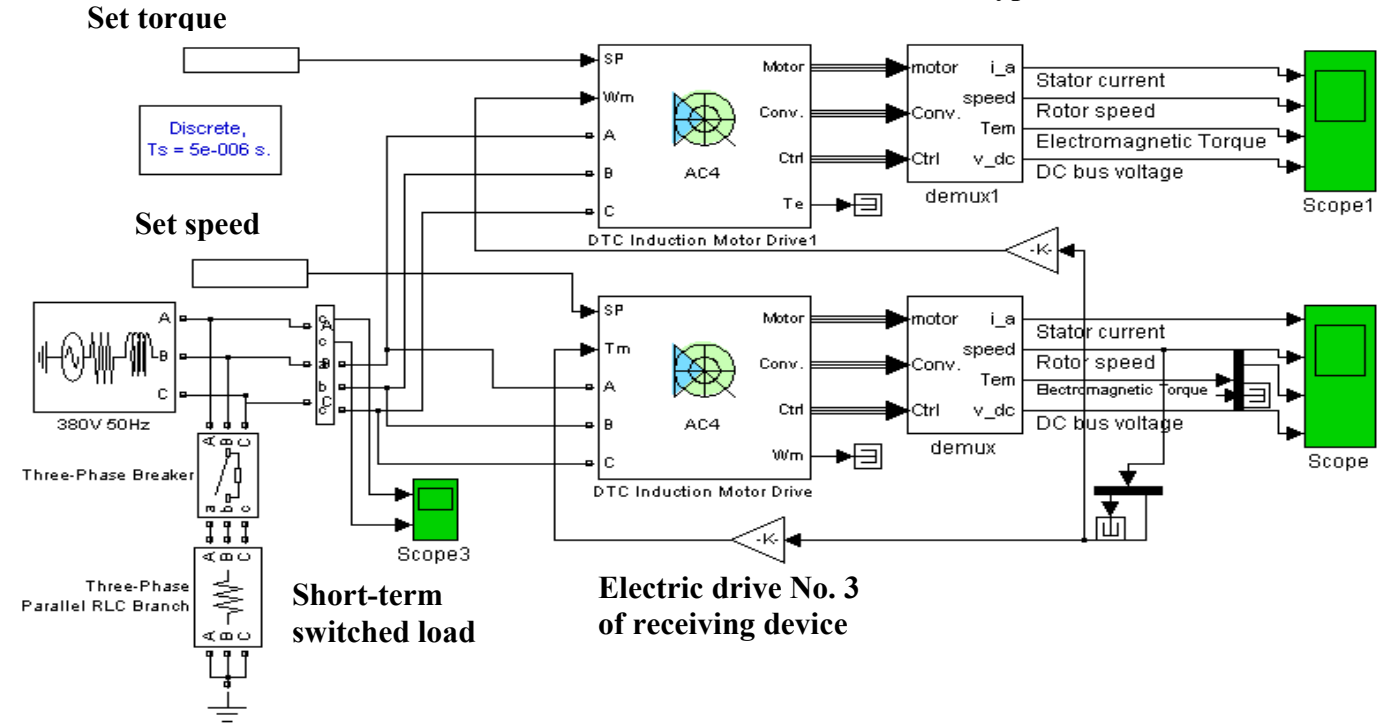

Fig. 2. Mathematical model of a system with two electric drives with vector control 
In this model, the effect of two drives No. 1 and No. 3, providing a set speed of the cable motion, is replaced by the equivalent action of one drive, so a system consisting of two drives is considered in the modeling. The model has a drive's receiving device, providing a set speed of shaft rotation of the asynchronous motor, and, consequently, a set speed of cable pulling. Also, there is a drive of the track-type device No. 2, which creates a set torque on the motor shaft, and, consequently, a set tension of the cable. Both drives are connected to a three-phase power supply. To model a short-term voltage failure mode, an additional active three-phase load is connected to this source with a key. To visualize the calculation results, the blocks of virtual oscilloscopes Display of the Simulink package are used, the inputs of which are connected to the corresponding communication lines.

Each of the two drive units, as in [7], model the electric drive operation based on an induction motor with vector control. This model contains an uncontrolled threephase rectifier, a three-phase inverter with pulse-width modulated current (PWM), an asynchronous motor, a speed controller and an inverter control unit. In order to avoid overvoltage at the rectifier output when the motor is switched on in the electric power generation mode, a special chopper block is located between the rectifier and the inverter, which provides the connection of a resistor shunting the storage capacitance when the voltage across the set value exceeds it. The block diagram of the drive realized by the DTC method is given in $[2,3,8]$.

The asynchronous machine model is used and consisted of an electrical part represented by a fourth-order state space model and a mechanical part model in the form of a second-order system. All electric variables and machine parameters were driven to the stator.

The initial equations of the electrical part of the machine are recorded for a two-phase coordinate system (the $d-q$ axis) and have the form:

$$
\begin{gathered}
V_{q s}=R_{s} i_{q s}+\frac{d}{d t} \varphi_{q s}-\omega \varphi_{d s}, \\
V_{d s}=R_{s} i_{d s}+\frac{d}{d t} \varphi_{d s}-\omega \varphi_{q s}, \\
V_{q r}^{\prime}=R_{r}^{\prime} i_{q r}^{\prime}+\frac{d}{d t} \varphi_{q r}^{\prime}+\left(\omega-\omega_{r}\right) \varphi_{d r}^{\prime}, \\
V_{d r}^{\prime}=R_{r}^{\prime} i_{d r}^{\prime}+\frac{d}{d t} \varphi_{d r}^{\prime}-\left(\omega-\omega_{r}\right) \varphi_{q r}^{\prime}, \\
T_{e}=1,5\left(\varphi_{d s} i_{d s}-\varphi_{q s} i_{d s}\right),
\end{gathered}
$$

where: $\varphi_{q s}=L_{s} i_{q s}+L_{m} i_{q r}^{\prime}, \quad \varphi_{d s}=L_{s} i_{q s}+L_{m} i_{d r}^{\prime}, \quad(8,9)$

$$
\begin{gathered}
\varphi_{q r}^{\prime}=L_{r}^{\prime} i_{q r}^{\prime}+L_{m} i_{q s}, \quad \varphi_{d r}^{\prime}=L_{r}^{\prime} i_{d r}+L_{m} i_{d s}, \\
L_{s}=L_{l s}+L_{m}, \quad L_{r}^{\prime}=L_{l r}^{\prime}+L_{m} .
\end{gathered}
$$

The mechanical part of the machine was described by two equations:

$$
\frac{d}{d t} \omega=\frac{1}{J}\left(T_{e}-F \omega-T_{m}\right), \quad \frac{d}{d t} \theta=\omega .
$$

The following symbols are used in the equations: $R_{s}$, $L_{l s}$ and $R_{r}^{\prime}, L_{l r}$ are the resistance and inductance of stator and rotor scattering; $L_{m}$ is the inductance of the magnetizing circuit; $L_{s}, L_{r}^{\prime}$ are the total inductances of the stator and rotor; $V_{q s}, i_{q s}$ and $V_{q r}^{\prime}, i_{q r}^{\prime}$ are the projections of the stator and rotor stresses and currents on the $q$ axis; $V_{d s}, i_{d s}$ and $V_{d r}^{\prime}, i_{d r}^{\prime}$ are the projections of the stator and rotor voltages and currents on the $d$ axis; $\varphi_{d s}, \varphi_{q s}$ and $\varphi_{d r}^{\prime}, \varphi_{q r}^{\prime}$, are the projections of the stator and rotor flux linkages on the $d$ and $q$ axes; $\omega$ is the angular velocity of the rotor; $\theta$ is the angular velocity of the rotor; $J$ is the rotor inertia torque; $T_{e}$ is the motor electromagnetic torque; $T_{m}$ is the static load moment; $F$ is the friction coefficient.

This mathematical model has become the basis for the one developed in the Simulink and for the virtual model of the asynchronous machine used in this paper. A number of parameters were calculated from the machine's passport data on the basis of the method described in [6]. At that, the asynchronous motor RA160MA4 (11 kW, $1460 \mathrm{rpm})$ was used in the drive's receiving device, and RA132S2 $(5.5 \mathrm{~kW}$, $1455 \mathrm{rpm}$ ) was used in the drive of the tracked chassis.

The analysis of modeling results. Fig. 3 shows the timing diagrams of the main characteristics of the drive's receiving device for the studied time period $-2 \mathrm{~s}$, corresponding to the start-up mode. The diagrams are in good agreement with the results given in [7]. The Fig. 3 shows the time-dependent current of the stator motor winding, the rotor speed, the electromagnetic torque on the motor shaft, and the reference voltage at the inverter input considering stable parameters of the supply network or network with infinitely large power.

Based on the modeling results, it can be noted that the current in the stator of the receiving device's motor changes in amplitude and frequency during start-up, and at the initial area the frequency is low and gradually increases as the motor accelerates. It is this trigger mode that is characterized by low energy consumption. The motor is monotonously accelerated to a set speed of $1200 \mathrm{rpm}$ for a time equal to $1.35 \mathrm{~s}$ and then accurately reproduces this predetermined rotation frequency in the subsequent time interval.

At the next stage of the research, dynamic processes in the drives were modeled with a short-time increase during $0.4 \mathrm{~s}$ of the supply voltage from an amplitude value of 380 $\mathrm{V}$ to various values up to $500 \mathrm{~V}$. Such a mode was modeled by connecting the drive to an additional voltage source of increased amplitude in a time point of $1.4 \mathrm{~s}$ (after reaching the steady state). The results of calculating these processes for the drive's receiving device are shown in Fig. 4.

Based on calculation results it follows that, although the inverter input voltage increases from $580 \mathrm{~V}$ to $800 \mathrm{~V}$, rotor speed does not change. That is, the studied system of the two drives is stable to short-time increases in the input voltage in the wide range.

At the next stage, dynamic processes in the drives were modeled for a short-time $(0.4 \mathrm{~s})$ network voltage failure from the amplitude value $u_{0}$ to the value $u_{0}-\Delta u$, with $\Delta u / u_{0}=0.54$. This mode was modeled by connecting to a power supply with a limited power of an additional three-phase load.

The calculating results of these processes for the drive's receiving device are shown in Fig. 5 for the phase voltage and in Fig. 6 for the stator current, the rotor speed, the electromagnetic torque and the inverter input voltage. 

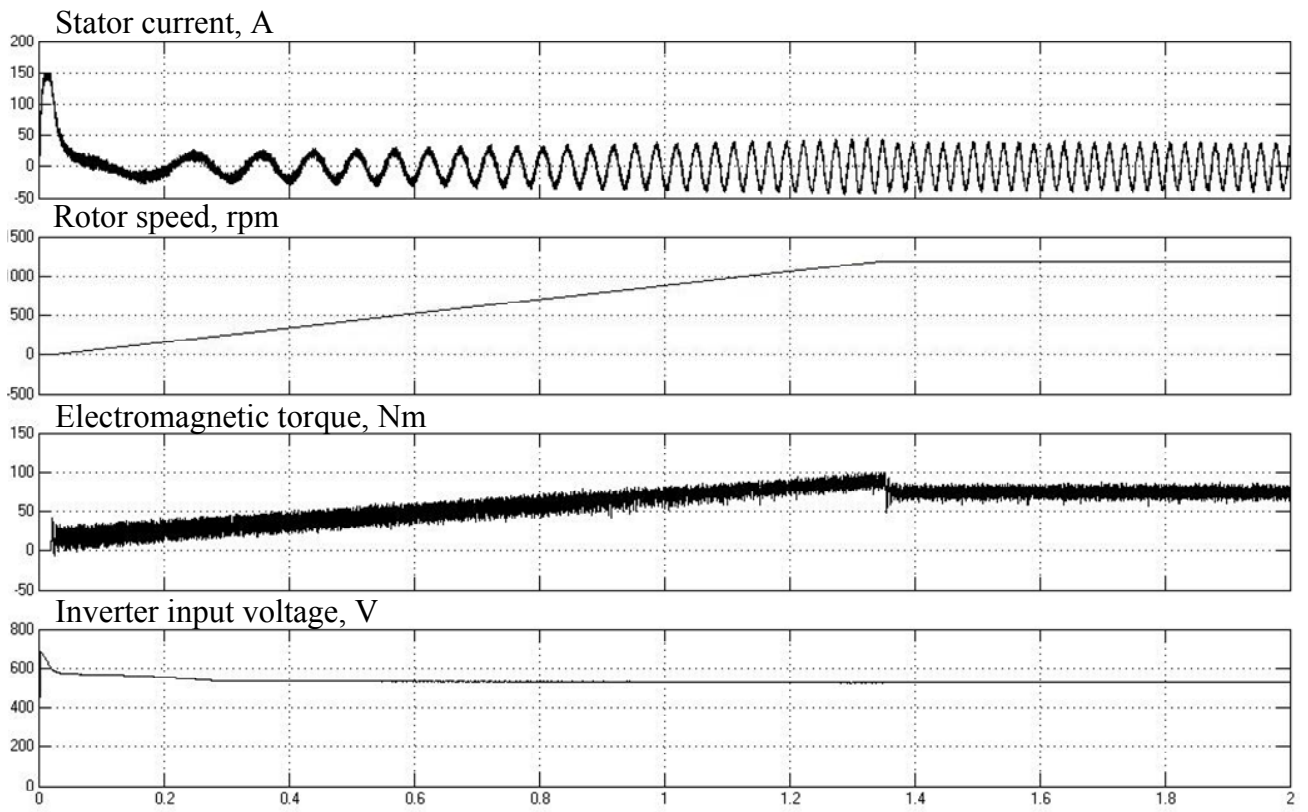

Time, $s$

Fig. 3. Timing diagrams of the main characteristics of the drive's receiving device for a period of time corresponding to the start-up mode

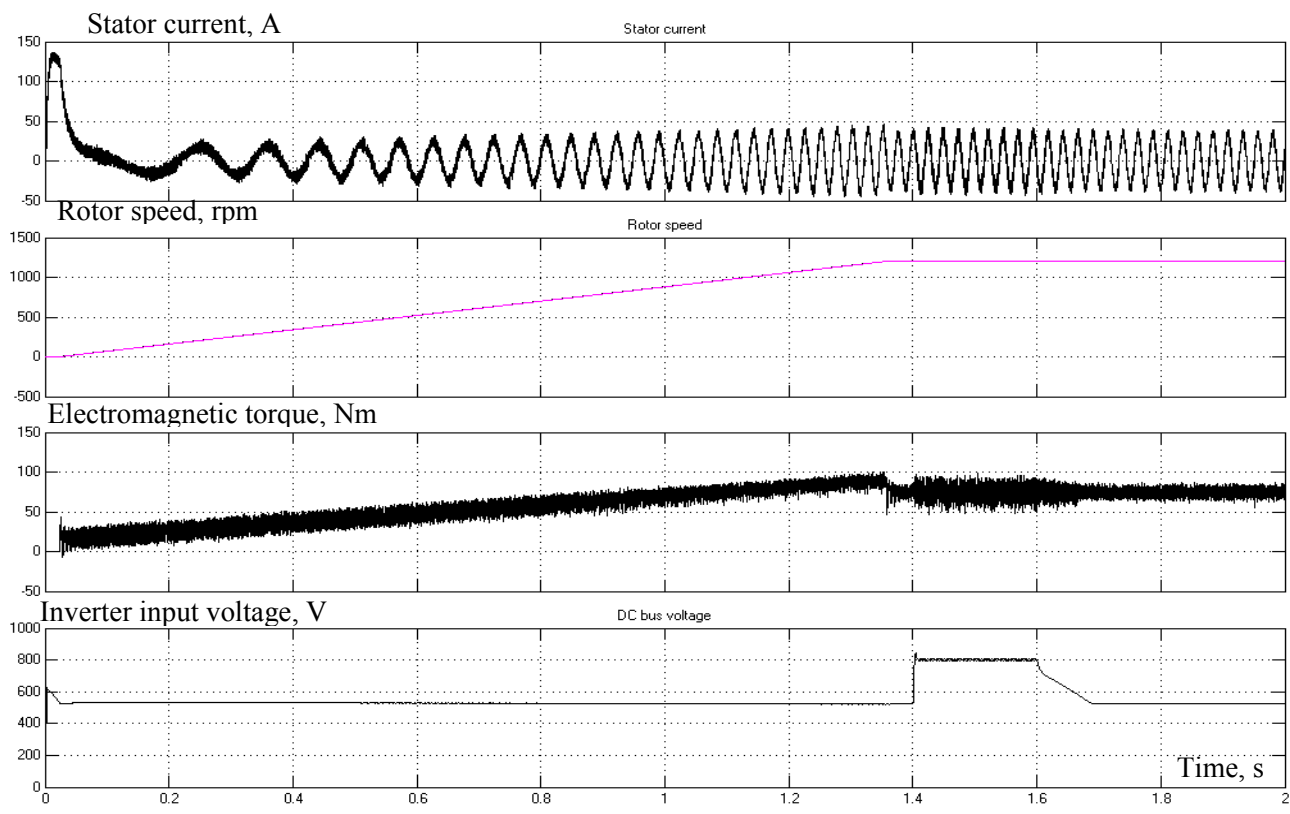

Fig. 4. Dynamic processes in the drive's receiving device at a short-term increase in the supply voltage

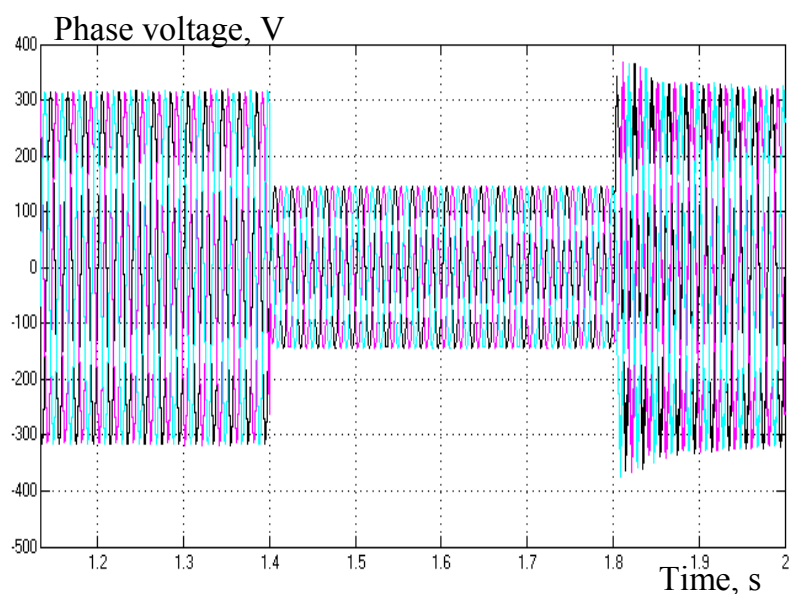

Fig. 5. Dependence of the phase voltage network on time
Fig. 6 shows that the voltage failure (time interval $1.4-1.8 \mathrm{~s})$ at the inverter input decreases, current level in the stator motor winding decreases, but vector control system increases the electromagnetic torque in order to work at the set speed. It can be seen that with this voltage failure, the electromechanical system, despite the torque increase, cannot work at the set rotor speed, which decreases at the end of this time interval by an amount $\Delta n \approx 430 \mathrm{rpm}$.

In order to obtain a quantitative dependence of the relative decrease in the rotor speed $\Delta n / n_{0}$ on the relative decrease in the network voltage $\Delta u / u_{0}$, calculations were carried out for different values of the load additionally connected to the network. These dependences are shown in Fig. 7. 


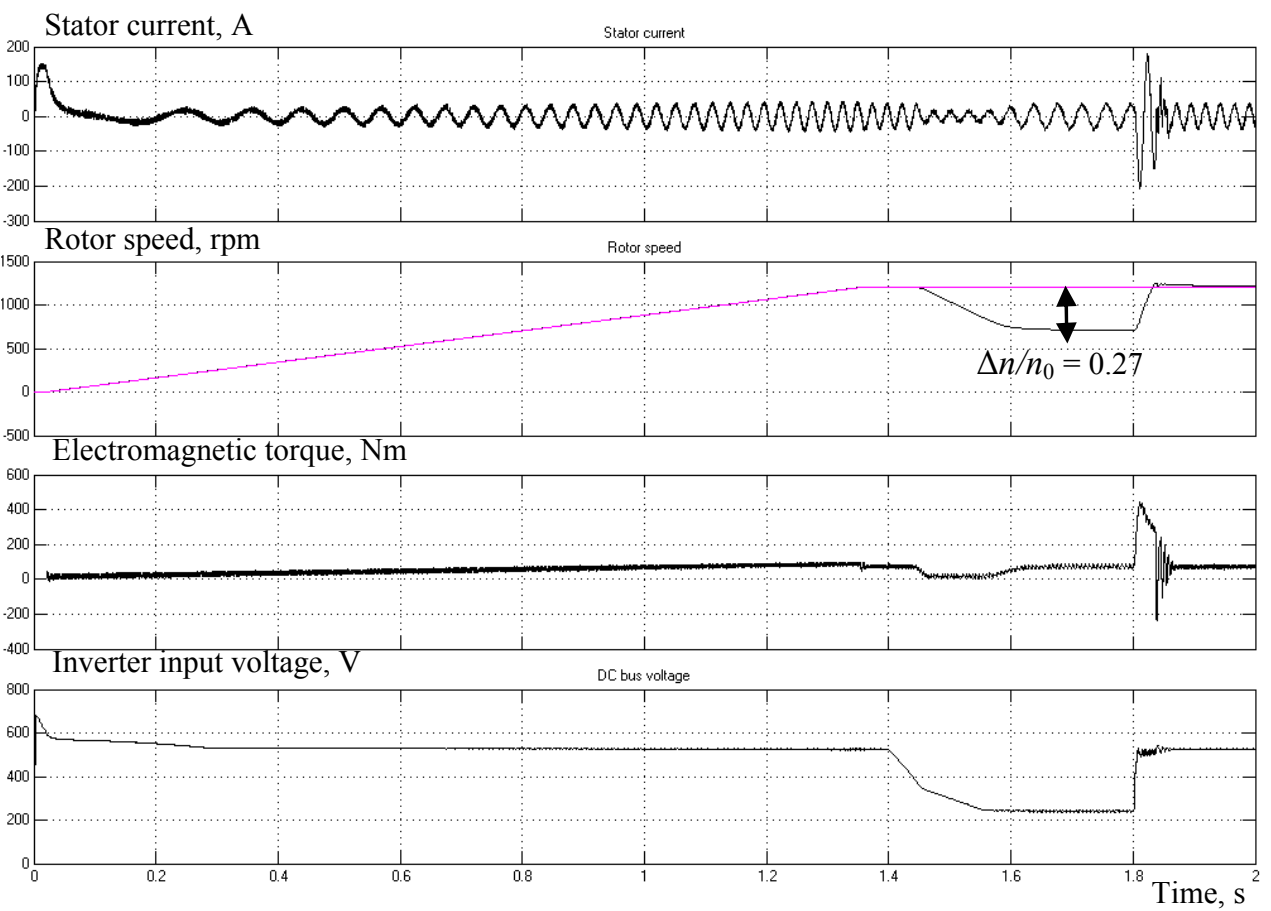

Fig. 6. Dynamic processes in the drive's receiving device at a short-term failure of the supply voltage

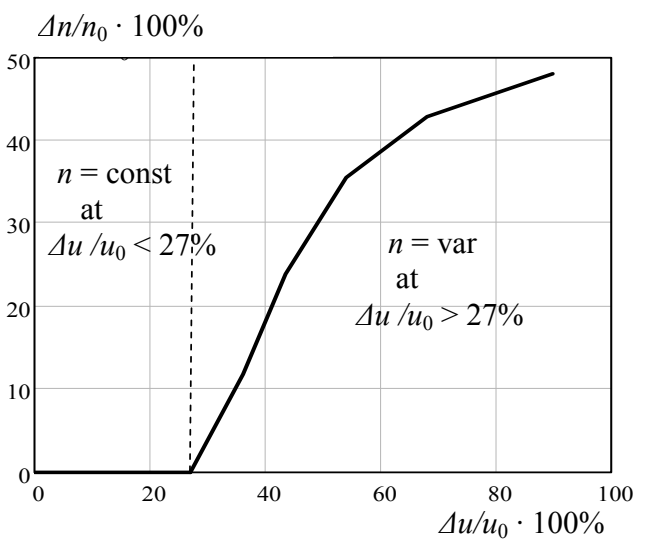

Fig. 7. Dependence of the relative decrease in the rotor speed $\Delta n / n_{0}$ of the electromechancal system on the relative decrease in the network voltage $\Delta u / u_{0}$

As can be seen from this figure, there is a threshold value for the voltage failure $\Delta u / u_{0} \cdot 100 \%=27 \%$, below which the drive ensures stabilization of the set speed with high accuracy. When this value is exceeded, the relative rotor speed $\Delta n / n_{0}$ increases, that is, the drive does not provide stabilization of the set speed. The obtained data on the threshold value of the voltage failure allow us to formulate the requirements for the parameters of power supply systems, taking into account their possible connection to additional power loads.

\section{Conclusions.}

1. A mathematical model has been developed to study the dynamic processes in the electromechanical system used in the production line for the extrusion coating of polyethylene insulation and semiconductive polymer layers on the current-carrying core of ultrahigh-voltage cables. The investigated system includes electric drives on the basis of frequency-controlled asynchronous motors and their load - moving current-carrying core with necessary speed and tension.
2. The coordination of electrical and mechanical parameters of the system is carried out and the analysis of its dynamic processes is made. It is determined that with a critical mass of the current-carrying core, the electromechanical system allows stabilizing the current-carrying core speed with the necessary accuracy at short-time failures in the supply voltage of no more than $27 \%$ of its amplitude value. This is one of the basic requirements for the parameters of power supply systems, taking into account their possible connection to additional power loads.

3 . It is also shown that this system is stable to a shortterm voltage increase for $0.2 \mathrm{~s}$ from a value of $380 \mathrm{~V}$ to $500 \mathrm{~V}$.

\section{REFERENCES}

1. Anuchin A., Shpak D., Aliamkin D., Briz F. Adaptive observer for field oriented control systems of induction motors. 57th International Scientific Conference on Power and Electrical Engineering of Riga Technical University (RTUCON), 2016, pp. 1-4. doi: 10.1109/RTUCON.2016.7763157.

2. Krause P.C., Wasynczuk O., Scott D.S. Analysis of Electric Machinery and Drive Systems. Wiley-IEEE Press, 2013. 680 p.

3. Trzynadlowski A. Control of Induction Motors. Academic Press, 2001. 225 p.

4. Bezprozvannych A.V., Kessaev A.G., Shcherba M.A. Frequency dependence of dielectric loss tangent on the degree of humidification of polyethylene cable insulation. Technical Electrodynamics, 2016, no.3, pp. 18-24. (Rus).

5. German-Galkin S.G. Matlab/Simulink. Proektirovanie mekhatronnykh sistem na PK [Matlab/Simulink. Designing mechatronic systems on a PC]. St. Petersburg, Korona-Vek Publ., 2008. 368 p. (Rus).

6. German-Galkin S.G., Cardonov G.A. Elektricheskie mashiny. Laboratornye raboty na PK [Electric machines. Lab. work on a PC]. St. Petersburg: Korona print Publ., 2003. 256 p. (Rus).

7. Zolotaryov V.M., Shcherba A.A., Podoltsev A.D. Modelling of dynamic processes in electromechanical system for the control of superhigh-voltage cable movement in slant extrusion-type line. Technical Electrodynamics, 2010, no.3, pp. 44-51. (Rus). 
8. Description of the application SimPowerSystems. Available at: www.mathworks.com (accessed 11 May 2017).

9. Peresada S.M. Nelineinoe $i$ adaptivnoe upravlenie $v$ elektromekhanicheskikh sistemakh $s$ vektorno-upravliaemymi elektrodvigateliami. Diss. dokt. techn. nauk [Nonlinear and adaptive control in electromechanical systems with vector-controlled electric motors. Doc. tech. sci. diss.]. Kyiv, 2007. 472 p. (Rus).

10. Pivnyak G.G., Volkov A.V. Sovremennye chastotnoreguliruemye asinkhronnye elektroprivody s chastotnoimpul'snoi moduliatsiei [Modern frequency-controlled asynchronous electric drives with frequency-pulse modulation]. Dnipropetrovsk, NGU Publ., 2006. 468 p. (Rus).

11. Chermalykh V.M., Chermalykh A.V., Maidansky I.Ya. Investigation of the dynamics and energy parameters of an asynchronous electric drive with vector control by the virtual simulation method. Bulletin of NTU «KhPI», 2008, no.30, pp. 41-45. (Rus).

12. Shcherba M.A., Podoltsev O.D. Electric field and current density distribution near water inclusions of polymer insulation of high-voltage cables in view of its nonlinear properties. Technical Electrodynamics, 2016, no.1, pp. 11-19. (Rus).

Received 15.11.2017
V.M. Zolotaryov ${ }^{1}$, Doctor of Technical Science,

M.A. Shcherba ${ }^{2}$, Candidate of Technical Science,

R.V. Belyanin ${ }^{1}$,

R.P. Mygushchenko ${ }^{3}$, Doctor of Technical Science,

I.M. Korzhov ${ }^{3}$,

${ }^{1}$ Private Joint-stock company Yuzhcable works,

7, Avtogennaya Str., Kharkiv, 61099, Ukraine,

phone +380 57 7545228, e-mail: zavod@yuzhcable.com.ua

${ }^{2}$ The Institute of Electrodynamics of the NAS of Ukraine,

56, prospekt Peremogy, Kiev-57, 03680, Ukraine, phone +380 44 3662460, e-mail: m.shcherba@gmail.com

${ }^{3}$ National Technical University «Kharkiv Polytechnic Institute»,

2, Kyrpychova Str., Kharkiv, 61002, Ukraine,

phone+380 57 7076116, e-mail: mrp1@ukr.net

How to cite this article:

Zolotaryov V.M., Shcherba M.A., Belyanin R.V., Mygushchenko R.P., Korzhov I.M. Electromechanical transient processes during supply voltage changing in the system of polymer insulation covering of the current-carrying core of ultra high voltage cables. Electrical engineering \& electromechanics, 2018, no.2, pp. 47-53. doi: 10.20998/2074272X.2018.2.08. 